\title{
COMPARISON OF THE RELIABILITY OF SNAP FOAL IG TEST, GAMMA-CHECK E TEST, REFRACTOMETRY AND ELECTROPHORESIS FOR DETERMINING THE IMMUNE STATUS OF NEWBORN FOALS IN THE FIRST HOURS OF LIFE
}

\author{
Luca Laura KUMMER ${ }^{1 *}$, Jan GOVAERE ${ }^{2}$ and Borisz EGRI ${ }^{1}$ \\ ${ }^{1}$ Faculty of Agricultural and Food Sciences, Széchenyi István University, Vár 2, \\ H-9200 Mosonmagyaróvár, Hungary; ${ }^{2}$ Faculty of Veterinary Medicine, \\ Ghent University, Merelbeke, Belgium
}

(Received 9 April 2018; accepted 20 November 2018)

\begin{abstract}
Twenty-eight warmblood mares were monitored during their late pregnancy in the Teaching Hospital of Ghent University. The reliability of two commercial assays (enzyme immunoassay and glutaraldehyde coagulation test) used for determining the $\mathrm{IgG}$ concentrations of their newborn foals was tested. Mammary secretions were examined at the time of foaling $\left(\mathrm{T}_{0}\right)$, and then $4\left(\mathrm{~T}_{1}\right)$ and $8\left(\mathrm{~T}_{2}\right)$ hours after foaling by refractometry and electrophoresis. The foals' blood IgG levels were measured at $T_{1}$ and $T_{2}$ as a routine clinical diagnostic examination using two different commercial test kits (SNAP Foal Ig and Gamma-Check E) and $\mathrm{T}_{0}, \mathrm{~T}_{1}$ and $\mathrm{T}_{2}$ samples were stored (at $-18^{\circ} \mathrm{C}$ ) for immunoglobulin (Ig) determination by electrophoresis. Differences between the results of refractometry and electrophoresis occurred in $27.8 \%$ of the colostrum analyses. Some serum IgG could be detected immediately post partum $\left(\mathrm{T}_{0}\right)$ in $75 \%$ of the foals, and $42.82 \%$ of the newborn foals acquired a serum concentration of more than $800 \mathrm{mg} / \mathrm{dl} \mathrm{IgG}$ within $8 \mathrm{~h}$ of birth. Compared to the electrophoresis, the glutaraldehyde test scored better $(85 \%)$ than the enzyme immunoassay (74\%), although both are accurate and safe to use since they clearly distinguish between safe and unsafe $\operatorname{IgG}$ concentrations.
\end{abstract} lostrum

Key words: Newborn foal, immunoglobulin, rapid test, refractometry, co-

Foals are immunocompetent but immunologically naïve and hypogammaglobulinaemic at birth (McGuire and Crawford, 1973), and therefore the adequate uptake of high-quality colostrum is essential for their future life (Rossdale and Ricketts, 1980; Horváth et al., 2005). Although parturition in the mare is usually easy and uneventful, a minimum level of surveillance is recommended to ensure a good start for the newborn (Govaere et al., 2011). Immunologic functions are suppressed in foaling mares and immature in neonatal foals, especially before colostrum intake (Aoki et al., 2013). The absorption of immunoglobulins

"Corresponding author; E-mail: kummer.luca@gmail.com; Phone: 0036 (30) 507-2778 
decreases $9 \mathrm{~h}$ after birth, but an adequate transfer of passive immunity is still possible at $9 \mathrm{~h}$ of age (Clément et al., 2002). The health status of foals during early life influences the horse's performance as an adult (Hemberg et al., 2010). In the United States, financial losses due to the failure of passive transfer (FPT) are estimated to reach 5 billion dollars every year (Perryman, 1981). Consequently, monitoring the immunity status of foals is of utmost importance and should be the first management step in the clinical evaluation of every newborn foal (Vincze et al., 2010). Research findings suggest that serum total globulin concentration can be used to predict gamma globulin concentration as a useful initial screening test for FPT in foals (Fouché et al., 2014). The purpose of this study was to assess a practical approach based on commercially available 'on-field' test kits (Metzger et al., 2006; de Bruijn et al., 2003), and to monitor the foals' immunity acquisition in the first hours of life. The time needed for acquiring this sufficient level of serum IgG by the foal has also been assessed, which may help clinicans to determine when they can expect the foal to be protected by its IgG concentration.

\section{Materials and methods}

Twenty-eight warmblood mares stalled at the clinic were under continuous surveillance during the last two weeks of pregnancy. The mares came from different stables and had different immunological backgrounds. Their body condition was 5-7 points (Henneke et al., 1983), their age was between 5 and 16 years, and parity varied between 1 and 5. All mares had a normal CTUP value (Combined Thickness of Uterus and Placenta; Troedsson, 2001; Baska-Vincze et al., 2014) checked in the last week of gestation by MyLab Class $C$ transrectal linear probe $(5-7.5 \mathrm{MHz})$, normal udder development without signs of premature lactation, and a foal in anterior presentation. Only mares exhibiting a normal course of parturition during phases 1, 2 and 3, and giving birth to a normal healthy foal were used in the study. Foals were artifically fed with $250 \mathrm{ml}$ colostrum of the dam from a bottle to make sure that they received the first amount of colostrum as soon as possible. The sampling protocol is shown in Table 1. Thereafter, foals were observed from a distance, clinical parameters were recorded and surveillance was assured to check timely standing, suckling and defecating reflexes as well as to ensure a normal mare-foal behaviour and bonding.

The 28 mares were examined three times: immediately at foaling $\left(\mathrm{T}_{0}\right)$, and then 4 and $8 \mathrm{~h}$ after foaling $\left(T_{1}\right.$ and $\left.T_{2}\right)$ the IgG content of the mammary secretions was checked by refractometry (REF) (ATC glucose refractometer, Minitube, Minitüb GmbH, Germany, 24400/0150) (Korosue et al., 2012) and stored at $-18^{\circ} \mathrm{C}$ for electrophoresis (Rumbaugh et al., 1978) later on. Twelve colostrum samples were not suitable for evaluation by the laboratory, and therefore a total of $72 \mathrm{co}-$ lostrum samples were analysed. The BRIX percentages measured by refractometer were compared to the results of electrophoresis (EPH) (Fig. 1). 


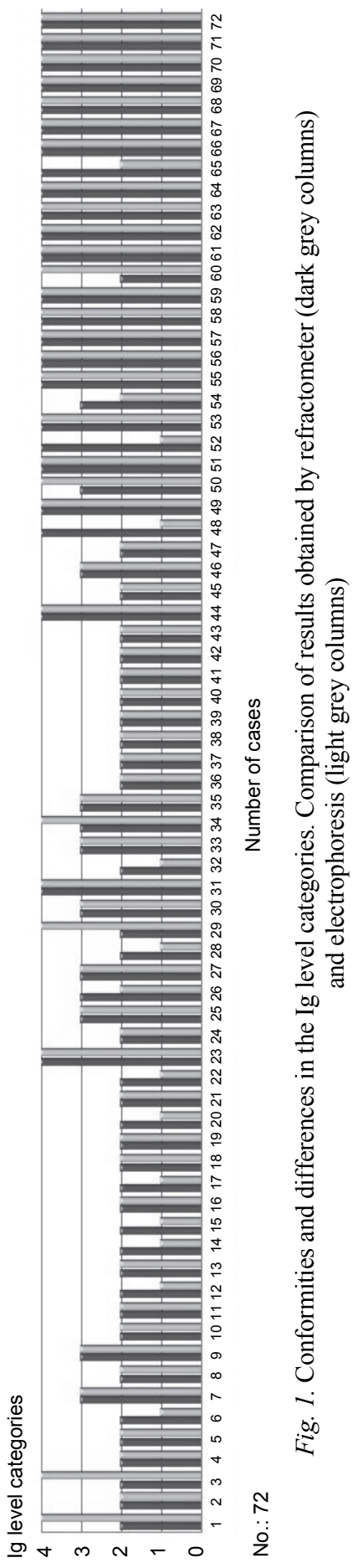


Table 1

Sampling protocol

\begin{tabular}{|c|c|c|c|c|}
\hline \multirow{3}{*}{$\begin{array}{l}\text { Time } \\
\text { point } \\
\mathrm{T}_{0}\end{array}$} & \multicolumn{2}{|c|}{ Mare } & \multicolumn{2}{|c|}{ Foal } \\
\hline & \multicolumn{2}{|c|}{ Colostrum sample } & \multirow{2}{*}{\multicolumn{2}{|c|}{$\begin{array}{c}\text { Blood sample } \\
\begin{array}{c}\text { ONLY: Store for EPH } \\
\text { (native tube) }\end{array}\end{array}$}} \\
\hline & Refractometry & Store for $\mathrm{EPH}$ & & \\
\hline $\mathrm{T}_{1}$ & Refractometry & Store for EPH & $\begin{array}{l}\text { EDTA tube } \\
\text { for on-field tests }\end{array}$ & $\begin{array}{c}\text { Store for EPH } \\
\text { (native tube) }\end{array}$ \\
\hline $\mathrm{T}_{2}$ & Refractometry & Store for EPH & $\begin{array}{l}\text { EDTA tube } \\
\text { for on-field tests }\end{array}$ & $\begin{array}{c}\text { Store for EPH } \\
\text { (native tube) }\end{array}$ \\
\hline
\end{tabular}

EPH: electrophoresis

The 28 foals were examined at two time points $\left(\mathrm{T}_{1}\right.$ and $\left.\mathrm{T}_{2}\right)$, but ten blood samples were unsuitable for evaluation, so a total of 46 samples were used to compare the commercially available tests (SNAP Foal Ig, Gamma-Check E test, and electrophoresis).

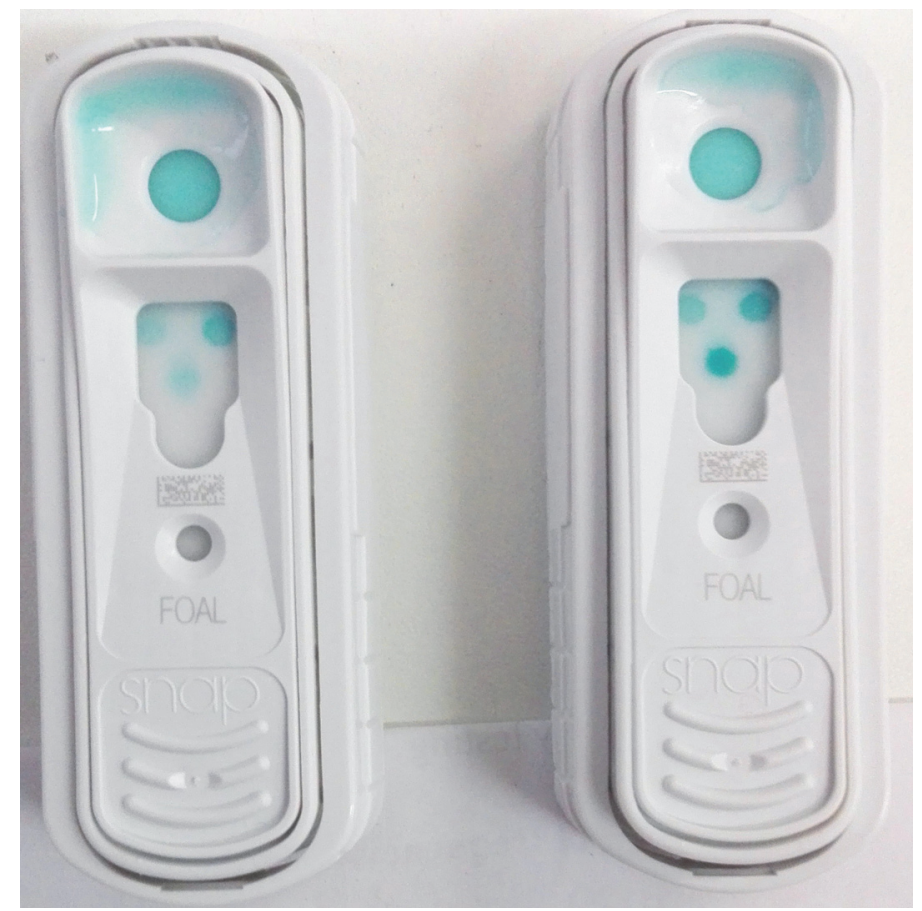

Fig. 2. Interpretation of test results less than $400 \mathrm{mg} / \mathrm{dl}$ (left) and more than $800 \mathrm{mg} / \mathrm{dl}$ (right) 
Fresh untreated blood samples (as serum for EPH) as well as EDTA samples, taken into a vacutainer, were obtained at each time (except EDTA samples at $\left.T_{0}\right)$. The EDTA samples $\left(T_{1}, T_{2}\right)$ were used for the 'on-field' tests. The serum was centrifuged with $2000 \mathrm{~g}$ for $20 \mathrm{~min}$ and stored at $-18{ }^{\circ} \mathrm{C}$ until analysis by EPH. All placentas were checked for gross pathology (LeBlanc, 1999). In order to assess the clinical status of the foals, standard measurements of clinical parameters were recorded at all time points (Martens, 1982; Szenci, 2004).

The Snap Foal test (SF test, IDEXX Laboratories), as described Pusterla et al. (2002), uses discolouration of a carrier impregnated with reagent alongside calibration standards indicating if the foal's blood contains less than $400 \mathrm{mg} / \mathrm{dl}$ immunoglobulins, more than $800 \mathrm{mg} / \mathrm{dl}$ immunoglobulins or immunoglobulin concentrations between the above two reference values (Fig. 2).

The Gamma-Check E test (GCh-E) by Plasvacc (USA) is designed to be a rapid screening test for foals, using whole blood or serum. The glutaraldehyde coagulation test method has been described previously (Beetson et al., 1985; Clabough et al., 1989). In brief, blood clotting with the prepared suspension within $10 \mathrm{~min}$ indicates that the $\mathrm{IgG}$ level is above $800 \mathrm{mg} / \mathrm{dl}$. Clot formation in $60 \mathrm{~min}$ means that the IgG level is between 400 and $800 \mathrm{mg} / \mathrm{dl}$ (McKinnon et al., 2011).

All colostrum and serum samples taken at time points $T_{0}, T_{1}$ and $T_{2}$ were analysed by electrophoresis (Zoolyx Veterinary Laboratory Services).

Conformities and differences between REF and EPH, and between the scores of the rapid tests and the EPH results were determined and analysed by IBM SPSS 23.0 statistics. Effectiveness of the diagnostic tests was compared to that of EPH. Both sensitivity and specificity, as well as the positive (PPV) and negative predictive values (NPV), and the accuracy of each test method were calculated at two different concentrations, with $800 \mathrm{mg} / \mathrm{dl}$ and $400 \mathrm{mg} / \mathrm{dl}$ taken as a threshold.

\section{Results}

The avarage values of the clinical parameters of neonatal foals at different time points are shown in Table 2 . The regularity was considered in the case of the heart rate and the respiratory rate. Muscle tonicity meant that the foals had extended front legs with lifted head and neck. In cases of irritation of the nasal mucosa, the foals gave forceful defensive reactions.

The Ig concentrations of the mares' colostrum and the foals' serum were compared in 19 cases after EPH (for 9 mare-foal pairs some data were missing, and thus these could not be included in this study). The changes of Ig concentrations are shown in Figs 3 and 4. The correlations are shown in Table 3, where the two cases from Fig. 4 were not taken into consideration, as they would have distorted the results. 
Table 2

Clinical parameters at different time points

\begin{tabular}{|c|c|c|c|c|}
\hline & $\begin{array}{l}\text { Heart rate, } \\
\text { per minute }\end{array}$ & $\begin{array}{l}\text { Respiratory rate, } \\
\text { per minute }\end{array}$ & Muscle tone & $\begin{array}{c}\text { Irritation of } \\
\text { nasal mucosa }\end{array}$ \\
\hline $\mathrm{T}_{0}$ & $\begin{array}{c}118.56( \pm 29.65) \\
\operatorname{reg} .: 85.7 \%\end{array}$ & $\begin{array}{c}60.36( \pm 14.01) \\
\operatorname{reg} .: 78.57 \%\end{array}$ & $92.86 \%$ & $92.86 \%$ \\
\hline $\mathrm{T}_{1}$ & $\begin{array}{c}101.46( \pm 16.46) \\
\text { reg.: } 100 \%\end{array}$ & $\begin{array}{c}57.25( \pm 20.35) \\
\text { reg.: } 92.86 \%\end{array}$ & $100 \%$ & $100 \%$ \\
\hline $\mathrm{T}_{2}$ & $\begin{array}{c}98.57( \pm 16.56) \\
\text { reg.: } 92.86 \%\end{array}$ & $\begin{array}{c}62.07( \pm 19.25) \\
\text { reg.: } 85.7 \%\end{array}$ & $100 \%$ & $100 \%$ \\
\hline
\end{tabular}

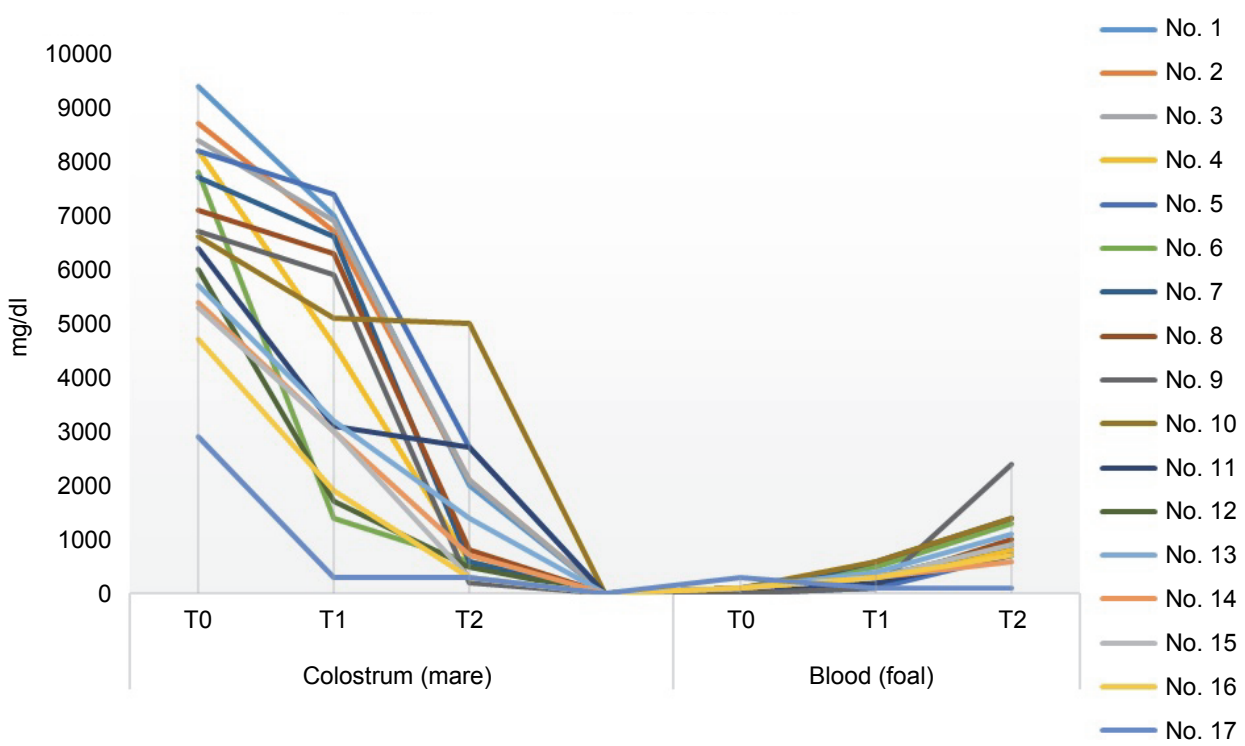

Fig. 3. Changes in the immunoglobulin (Ig) concentration of the colostrum (mare) and blood (foal) post partum

The categories of the colostrum analyses are shown in Table 4. The data did not show normal distribution, and thus a Spearman's rho correlation test was used. A strong positive connection was seen between results obtained by REF and $\mathrm{EPH}$, resulting in a correlation coefficient of 0.7 . Differences between the results obtained by REF and EPH occurred for 20 samples (27.8\%) (Table 5).

In $75 \%$ of the foals some serum IgG could be detected (using EPH later on) immediately post partum $\left(\mathrm{T}_{0}\right)$. In most cases the Ig level varied around $100 \mathrm{mg} / \mathrm{dl}$ and in $7.14 \%$ of the cases the Ig level was $200-300 \mathrm{mg} / \mathrm{dl}$ immediately after delivery. Although, on average, at $\mathrm{T}_{0}$ the naive serum Ig concentrations of newborn 
foals were less than $300 \mathrm{mg} / \mathrm{dl}$ with an average of $85 \mathrm{mg} / \mathrm{dl}$ as assessed by EPH. By $\mathrm{T}_{1}, 14.29 \%$ of the foals had acquired a serum Ig concentration of $600 \mathrm{mg} / \mathrm{dl}$, and at $\mathrm{T}_{2}$ a serum IgG level above $600 \mathrm{mg} / \mathrm{dl}$ was measured in $78.57 \%$ of the foals, with $42.82 \%$ of the newborn foals having higher than $800 \mathrm{mg} / \mathrm{dl}$ immunoglobulin level in their serum $8 \mathrm{~h}$ post partum.

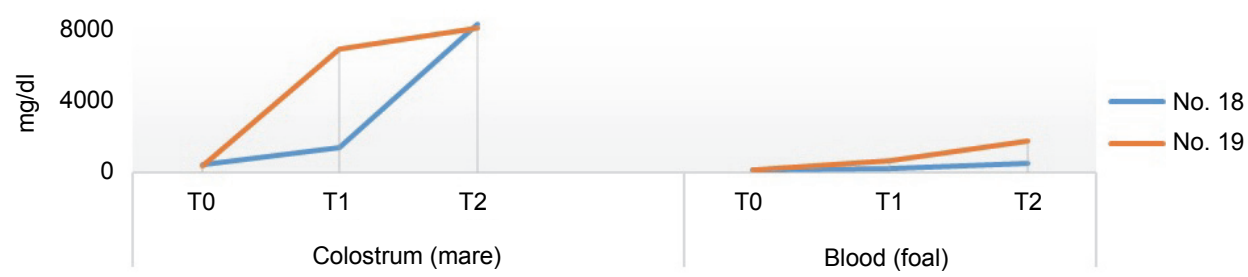

Fig. 4. Changes in the Ig concentration of the colostrum (mare) and blood (foal) post partum in the two cases $(10.5 \%)$ with delayed culmination of colostral Ig concentration

Table 3

Correlations between the immunoglobulin concentrations of mare's colostrum and foal's serum

\begin{tabular}{lc}
\hline Time points & Correlation coefficient \\
\hline Mare $\mathrm{T}_{0}-$ Foal $\mathrm{T}_{0}$ & -0.357 \\
Mare $\mathrm{T}_{0}-$ Foal $\mathrm{T}_{1}$ & -0.213 \\
Mare $_{0}-$ Foal $\mathrm{T}_{2}$ & 0.281 \\
Mare $\mathrm{T}_{1}-$ Foal $\mathrm{T}_{1}$ & -0.281 \\
Mare $\mathrm{T}_{1}-$ Foal $\mathrm{T}_{2}$ & 0.326 \\
Mare $\mathrm{T}_{2}-$ Foal $\mathrm{T}_{2}$ & -0.068 \\
\hline
\end{tabular}

Table 4

Colostrum quality categories (Cash, 1999)

\begin{tabular}{lccc}
\hline Category & Colostrum quality & Refractometry, Brix (\%) & Electrophoresis, IgG conc. $(\mathrm{g} / \mathrm{l})$ \\
\hline 1 & Very good & $>30$ & $>80$ \\
2 & Good & $20-30$ & $50-80$ \\
3 & Fair & $15-20$ & $28-50$ \\
4 & Poor & $<15$ & $0-28$ \\
\hline
\end{tabular}

A strong positive correlation of $0.764,0.845$ and 0.849 was found between Snap Foal (SF) and EPH, between Gamma Check-E (GCh-E) and EPH, and between SF and GCh-E, respectively. 


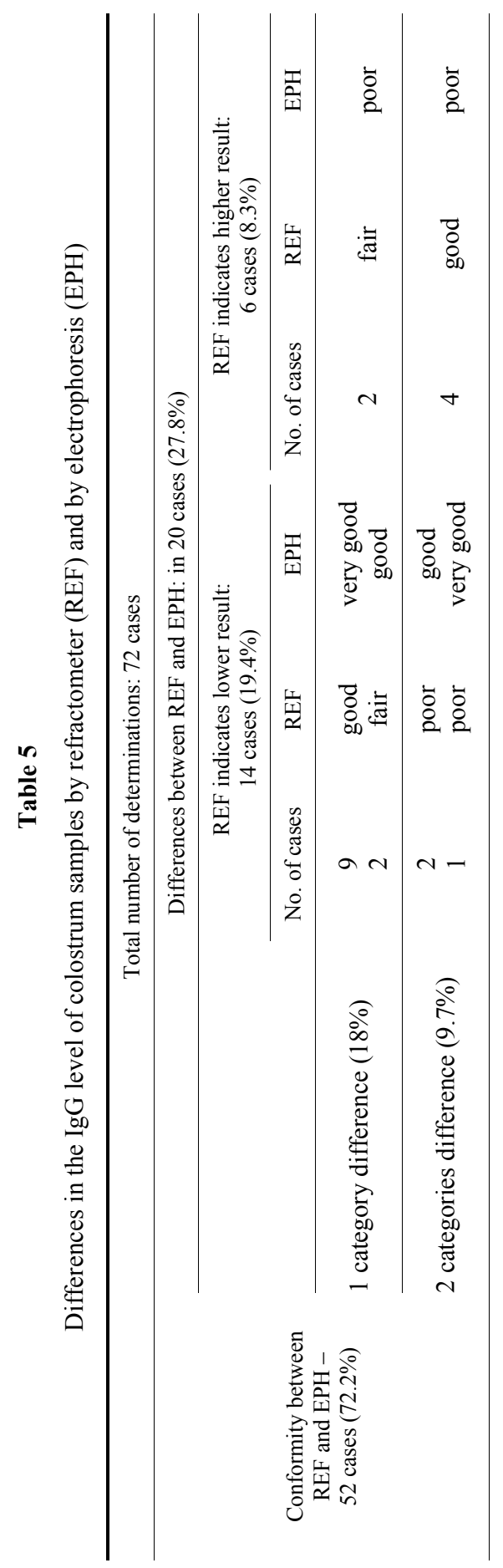


Differences were seen on 22 occasions (in $47.83 \%$ of the cases) when comparing the SF test results with the EPH findings. When comparing the GChE with the EPH results, a difference was found in 17 samples (36.96\%). In all these cases, EPH demonstrated lower Ig concentrations than the on-field tests (the details are shown in Table 6).

Table 6

Differences between the on-field tests and electrophoresis

\begin{tabular}{|c|c|c|c|c|}
\hline \multicolumn{5}{|c|}{ Total number of determinations: 46 cases } \\
\hline \multirow{7}{*}{$\begin{array}{l}\text { Conformity } \\
\text { between SF and EPH: } \\
24 \text { cases } \\
(52.17 \%)\end{array}$} & \multicolumn{4}{|c|}{ Differences between SF and EPH: 22 cases (47.83\%) } \\
\hline & \multirow{6}{*}{$\begin{array}{l}\text { SF indicates } \\
\text { lower result: } \\
0 \text { case } \\
(0 \%)\end{array}$} & \multicolumn{3}{|c|}{ SF indicates higher result: 22 cases $(47.83 \%)$} \\
\hline & & Cases & SF & $\mathrm{EPH}$ \\
\hline & & $8(17.39 \%)$ & $400-800$ & $<400$ \\
\hline & & $9(19.57 \%)$ & $>800$ & $600-800$ \\
\hline & & $3(6.52 \%)$ & $>800$ & $400-600$ \\
\hline & & $2(4.35 \%)$ & $>800$ & $<400$ \\
\hline \multicolumn{5}{|c|}{ Total number of determinations: 46 cases } \\
\hline \multirow{6}{*}{$\begin{array}{l}\text { Conformity } \\
\text { between } \\
\text { GCh-E and EPH: } \\
29 \text { cases } \\
(63.04 \%)\end{array}$} & \multicolumn{4}{|c|}{ Differences between GCh-E and EPH: 17 cases } \\
\hline & \multirow{5}{*}{$\begin{array}{c}\text { GCh-E } \\
\text { indicates } \\
\text { lower result: } \\
0 \text { case } \\
(0 \%)\end{array}$} & \multicolumn{3}{|c|}{ GCh-E indicates higher result: 17 cases $(36.96 \%)$} \\
\hline & & Cases & GCh-E & $\mathrm{EPH}$ \\
\hline & & $8(17.39 \%)$ & $400-800$ & $<400$ \\
\hline & & $7(15.22 \%)$ & $>800$ & $600-800$ \\
\hline & & $2(4.35 \%)$ & $>800$ & $400-600$ \\
\hline
\end{tabular}

SF: SNAP Foal test; GCh-E: Gamma-Check E test; EPH: electrophoresis

Sensitivity, specificity, PPV, NPV and accuracy were calculated at two different measurement thresholds: $800 \mathrm{mg} / \mathrm{dl}$ and $400 \mathrm{mg} / \mathrm{dl}$ Ig concentration, respectively (Table 7). Sensitivity $(800 \mathrm{mg} / \mathrm{dl})$ of the GCh-E test and the SF test was 0.8 and 0.53 , respectively. Also at the measurement threshold of $400 \mathrm{mg} / \mathrm{dl}$ the sensitivity of the GCh-E test (0.53) was higher than that of the SF test $(0.38)$. The specificity of all test methods was 1 . The PPV was 1 for all test methods and both threshold levels, but the NPV (at a limit of $800 \mathrm{mg} / \mathrm{dl}$ ) was 0.73 for GCh-E and 0.53 for SF. The NPV (at the $400 \mathrm{mg} / \mathrm{dl}$ limit) was 0.79 for GCh-E and 0.75 for SF. The accuracy of the GCh-E and SF was $87 \%$ and $70 \%$, respectively, at the threshold of $800 \mathrm{mg} / \mathrm{dl}$ and $83 \%$ and $78 \%$, respectively, at the $400 \mathrm{mg} / \mathrm{ml}$ concentration. 
Table 7

Comparison of the characteristics of SF and GCh-E Ig tests with electrophoresis

\begin{tabular}{lcccc}
\hline & SF test & SF test & GCh-E & GCh-E \\
& $400 \mathrm{mg} / \mathrm{dl}$ & $800 \mathrm{mg} / \mathrm{dl}$ & $400 \mathrm{mg} / \mathrm{dl}$ & $800 \mathrm{mg} / \mathrm{dl}$ \\
\hline Sensitivity & 0.38 & 0.53 & 0.5 & 0.8 \\
Specificity & 1 & 1 & 1 & 1 \\
Positive predictive value & 1 & 1 & 1 & 1 \\
Negative predictive value & 0.75 & 0.53 & 0.79 & 0.73 \\
Accuracy & $78 \%$ & $70 \%$ & $83 \%$ & $87 \%$ \\
\hline
\end{tabular}

\section{Discussion}

Only healthy foals were included in this study. Accordingly, the clinical parameters - measured as part of the vitality testing immediately after parturition $\left(\mathrm{T}_{0}\right), 4 \mathrm{~h}$ post delivery $\left(\mathrm{T}_{1}\right)$ and at $8 \mathrm{~h}$ of age $\left(\mathrm{T}_{2}\right)$ - provided consistent reference values in the very early life of neonatal foals, which can be used for comparison with other newborn foals in the future.

In most cases the colostral Ig concentration of mares reaches its peak around the time of foaling and then it starts to decrease. With the foal's nursing, the neonate's serum Ig concentration increases. In two cases (10.5\%; Fig. 4) the mare's colostral Ig content culminated only after a few hours post partum, and thus the foal could not take up the highest amount even if it stood up and suckled earlier. For this reason these two cases were not included in the calculation of correlations. Weak correlations were found between the Ig concentrations of the mare's colostrum and the foal's serum at the different time points, with the exception of $\mathrm{T}_{2}$. At a given time point the correlations were always negative, which means that colostral Ig concentration is inversely related to serum Ig concentration at the same time point. The highest positive correlation was found between $\mathrm{T}_{1}$ colostrum and $\mathrm{T}_{2}$ serum samples.

The equine placenta of epitheliochorial type does not allow an easy transit of larger molecules like immunoglobulins, resulting in agammaglobulinaemic neonates at birth (Egri and László, 1991; Szenci, 1993). Even so, infrequently some IgG and IgM can be found in the blood of the newborn foal (Koterba et al., 1990), which indicates that some degree of antibody formation occurs already in utero (Perkins and Wagner, 2015). In this study, only $25 \%$ of the foals did not have any serum Ig as shown by EPH, while some serum $\mathrm{Ig}(85 \mathrm{mg} / \mathrm{dl})$ was demonstrated in $75 \%$ of the foals in the immediate postpartum period.

When assessing colostrum quality, a strong correlation between the refractometer values ( $\%$ BRIX) and the EPH results was seen (correlation coefficient $=$ 0.7 ). This suggests that the refractometer is a very good instrument for assessing colostrum quality (Korosue et al., 2012), besides its use to predict an impending 
parturition (Chavatte-Palmer et al., 2001). According to the findings of another study, however, BRIX refractometry is only a moderately accurate method for predicting foaling within $60 \mathrm{~h}$ in multiparous mares (Stout et al., 2011).

The reported $27.8 \%(20 / 72)$ discrepancy between the results obtained by REF and EPH is a major disadvantage of the test with economic and medical implications. When REF underestimated the Ig concentrations in comparison with the EPH results (14/20), colostrum or plasma supplementation of the foals would have been an unnecessary expenditure. If REF overestimates the Ig concentrations compared to the actual (i.e. EPH) values, this might imply a serious threat to the foals' health if the serum IgG levels are not monitored later on.

Although previous papers recommended to determine the serum IgG levels at $18 \mathrm{~h}$ of age (LeBlanc, 2001), in the described management practice (including the 250-ml bottle feeding), our results show that normal healthy foals can acquire the minimum protective levels much earlier. In this study, $42.82 \%$ of the newborn foals acquired a serum IgG concentration exceeding $800 \mathrm{mg} / \mathrm{dl}$ within $8 \mathrm{~h}$ of birth. By $18 \mathrm{~h}$ of age all the foals had achieved the $800 \mathrm{mg} / \mathrm{dl}$ Ig level except two neonates; however, the Ig concentration of the latter also increased above this level by the end of the first day of life.

The use of rapid 'on-field' tests for determining the immunoglobulin status in the very early period after birth is important in order to supply immunoglobulin-deficient foals with immunoglobulins as early as possible. The diagnostic test should be reliable, easy to use and economical. Both tests (SF and GCh-E) are user friendly but should be kept at $2-8{ }^{\circ} \mathrm{C}$. The GCh-E test is cheaper and had a better sensitivity and accuracy than SF in this trial, but the SF test has advantages in compromised foals or in the case of haemolysed samples. In this study only healthy foals were taken into account, which explains why the GCh-E test could be used in a reliable way.

Both of the two rapid 'on-field' tests evaluated in this study showed a strong correlation with the EPH. In this study, the GCh-E test scored better than the SF test (Table 7). The sensitivity of the GCh-E test ( 0.8 at the level of 800 and 0.5 at the level of $400 \mathrm{mg} / \mathrm{dl})$ was better than that of the SF test $(0.53$ at 800 and 0.38 at $400 \mathrm{mg} / \mathrm{dl}$ ). The specificity and the PPV were the same (1) for both methods.

In general, when discordance between the on-field tests and the EPH occurred, all the rapid diagnostic tests showed higher IgG concentrations than EPH. Those cases in which the on-field test predicts a 'good' level of protection but the actual (EPH) IgG level does not reach even the $600 \mathrm{mg} / \mathrm{dl}$ limit, pose a huge risk to the health status of the newborn foal.

Day et al. (2003) compared the performance and predictive abilities of four commercially available foal IgG tests (including the SF and GCh-E tests) using turbidimetric immunoassay as a reference standard. In that report, the GCh-E test had a higher sensitivity than the SF test, but in terms of specificity the SF test 
had higher values compared to the GCh-E, and also the accuracy of the GCh-E test was higher than that of the SF test. In the present study, the sensitivity of the GCh-E was also found to be higher compared to the SF, while regarding the specificity the two tests were equivalent. The GCh-E was found to be superior also in terms of accuracy ( $85 \%)$ as compared to the SF test (74\%).

According to our results obtained in healthy uncompromised foals, the GCh-E scored better in both accuracy and sensitivity compared to the SF. However, the use of SF in foals where an impending inflammation is suspected, can provide an advantage over the GCh-E. In non-compromised foals the glutaraldehyde test (GCh-E) might be a justified choice to assess the foals' immunity since it is less expensive than the enzyme immunoassay (SF); however, if an inflammatory process is suspected, the SF test might be preferred to the GCh-E test, because in the acute phase of inflammation, when fibrinogen levels are high (Vajdovich and Ribiczeyné, 1999), or with haemolysed samples the GCh-E has been reported to give false positive test results. In case of doubt or in the case of a mismatch between test results and clinical findings, electrophoresis might be indicated. The use of a refractometer is recommended, and it can be a very good additional tool for assessing colostrum quality, and thus to predict the chances of the newborn foal. Eight hours after birth is too early for determining the IgG concentration, but the optimum time point can be earlier than 18 hours. Further investigations are needed to determine the best time point for using on-field tests.

\section{Acknowledgements}

The publication is supported by the EFOP-3.6.3.-VEKOP-2017-00008 project. The project is co-financed by the European Union and the European Social Fund.

\section{References}

Aoki, T., Honda, H. and Ishii, M. (2013): Immunologic profiles of peripheral blood leucocytes and serum immunoglobulin $\mathrm{G}$ in perinatal mares and neonatal foals (Heavy Draft horse). J. Eq. Vet. Sci. 33, 989-995.

Baska-Vincze, B., Rózsás, J., Baska, F. and Szenci, O. (2014): Evaluation of foetal well-being by transabdominal ultrasonography in the mare [in Hungarian, with English abstract]. Magy. Allatorvosok 136, 195-204.

Beetson, S. A., Hilbert, B. J. and Mills, J. N. (1985): The use of the glutaraldehyde coagulation test for detection of hypogammaglobulinemia in neonatal foals. Aust. Vet. J. 62, 279-281.

Cash, R. S. G. (1999): Colostral quality determined by refractometry. Eq. Vet. Educ. 11, 36-38.

Chavatte-Palmer, P., Duvaux-Ponter, C. and Clement, F. (2001): Passive transfer of immunity in horses. Pferdeheilkunde 17, 669-672.

Clabough, D. L., Conboly, H. S. and Roberts, M. C. (1989): Comparison of four screening techniques for the diagnosis of equine neonatal hypogammaglobulinemia. J. Am. Vet. Med. Assoc. 194, 1717-1720. 
Clément, F., Duvaux-Ponter, C., Arnaud, G., Piot, M., Maubois, J. L., Grongnet, J. F., Brugére, L., Tournié, M., Detrimont, L. and Chavatte-Palmer, P. (2002): Efficiency of IgG absorption in the foal. Theriogenology 58, 805-808.

Day, A. G., McVicker, J. K. and Rouse, G. C. (2003): Performance of four commercially available foal IgG tests compared to turbidimetric immunoassay (TIA) testing. Midland BioProducts Corporation, Boone.

de Bruijn, C. M., Wensing, T. and van Nieuwstadt, R. A. (2003): Reliability of the glutaraldehyde test to measure gamma-globulin levels in foals and the use of this test to check colostrum intake of foals. Tijdschr. Diergeneeskd. 8, 240-246.

Egri, B. and László, I. (1991): Monitoring of the adequate immunoglobulin-supplied newborn and suckling foals [in Hungarian]. Phylaxia Állatorvosi Közlemények 27, 18-22.

Fouché, N., Graubner, C. and Howard, J. (2014): Correlation between serum total globulins and gamma globulins and their use to diagnose failure of passive transfer in foals. Vet. J. 202, 384-386.

Govaere, J., Hoogewijs, M., DeSchauwer, C., Van Aert, M. and DeKruif, A. (2011): Dystocia management in mares. Intas Polivet 12, 329-339.

Hemberg, E., Kindahl, H., Lundeheim, N. and Einarsson, S. (2010): Relationships between early foal health, future performance and their dams reproductive health. Reprod. Dom. Anim. 45, 817-820.

Henneke, D. R., Potter, G. D., Kreider, J. L. and Yeates, B. F. (1983): Relationship between condition score, physical measurements and body fat percentage in mares. Equine Vet. J. 15, $371-372$.

Horváth, D., Horváth, A., Kutasi, O., Bakos, Z. and Szenci, O. (2005): Practical aspests of the immunoglobulin supply state in newborn foals (in Hungarian, with English abstract). Magy. Allatorvosok 127, 3-11.

Korosue, K., Murase, H., Sato, F., Ishimaru, M., Kotoyori, Y. and Nambo, Y. (2012): Correlation of serum IgG concentration in foals and refractometry index of the dam's pre- and postparturient colostrums: An assessment for failure of passive transfer in foals. J. Vet. Med. Sci. 74, 1387-1395.

Koterba, A. M., Drummond, W. H. and Kosch, P. C. (1990): Equine Clinical Neonatology. Lea \& Febiger, Philadelphia.

LeBlanc, M. M. (1999): Diseases involving the placenta. In: Colahan, P. T., Mayhew, I. G., Merritt, A. M. and Moore, J. N. (eds) Equine Medicine and Surgery. Vol. II., 5th edition. Mosby, St. Louis. pp. 1193-1199.

LeBlanc, M. M. (2001): Update on passive transfer of immunglobulins in the foal. Pferdeheilkunde $17,662-665$.

Martens, R. J. (1982): Neonatal foal diseases: classification, characterization and predisposing factors. In: Proceedings of the 28th American Association of Equine Practitioners (AAEP) Convention. pp. 341-357.

McGuire, T. C. and Crawford, T. B. (1973): Passive immunity in the foal: Measurement of immunoglobulin classes and specific antibody. Am. J. Vet. Res. 34, 1299-1303.

McKinnon, A. O., Squires, E. L., Vaala, W. E. and Varner, D. D. (2011): Equine Reproduction. 2nd edition. Wiley-Blackwell, Chichester.

Metzger, N., Hinchcliff, K. W., Hardy, J., Schwarzwald, C. C. and Wittum, T. (2006): Usefulness of a commercial equine IgG test and serum protein concentration as indicators of failure of transfer of passive immunity in hospitalized foals. J. Vet. Intern. Med. 20, 382-387.

Perkins, G. A. and Wagner, B. (2015): The development of equine immunity: Current knowledge of immunology in the young horse. Equine Vet. J. 47, 267-274.

Perryman, L. E. (1981): Immunological management of young foals. Compend. Contin. Educ. Pract. Vet. 3, 223-228. 
Pusterla, N., Pusterla, J. B., Spier, S. J., Puget, B. and Watson, J. L. (2002): Evaluation of the SNAP foal IgG test for the semiquantitative measurement of immunoglobulin $\mathrm{G}$ in foals. Vet. Rec. 151, 258-260.

Rossdale, P. D. and Ricketts, S. W. (1980): Equine Stud Farm Medicine. 2nd edition. Lea \& Febiger, Philadelphia. $165 \mathrm{pp}$.

Rumbaugh, G. E., Ardans, A. A., Ginno, D. and Trommershausen-Smith, A. (1978): Measurement of neonatal equine immunoglobulins for assessment of colostral immunoglobulin transfer: comparison of single radial immunodiffusion with the zinc sulfate turbidity test, serum electrophoresis, refractometry for total serum protein, and the sodium sulfite precipitation test. J. Am. Vet. Med. Assoc. 172, 321-325.

Stout, T. A. E., Koekkoek, J. and Hendriks-Onstein, W. K. (2011): BRIX refractometric analysis of mammary secretions is a poor predictor of impending parturition in mares. Pferdeheilkunde 27, 287-292.

Szenci, O. (1993): Things to do with the newborn foal. In: Haraszti, J. and Zöldág, L. (eds) The Obstetrics and Reproductive Biology of Domestic Animals [in Hungarian]. Mezőgazda Kiadó, Budapest. 262 pp.

Szenci, O. (2004): Practical aspects of the newborn foal's care [in Hungarian]. XII. Equine Medical Congress, Large Animal Clinic, Üllö, Hungary. pp. 6-23.

Troedsson, M. H. T. (2001): Ultrasonographic evaluation of the equine placenta. Pferdeheilkunde 17, 583-588.

Vajdovich, P. and Ribiczeyné, Sz. P. (1999): Other, less common investigations. In: Gaál, T. (ed.) Veterinary Clinical Laboratory Diagnostics [in Hungarian]. Sík Kiadó, Budapest. pp. 385-429.

Vincze, B., Horváth, D., Kulik, M., Ritter, D. and Szenci, O. (2010): Control of immunglobulin concentration of newborn foal and colostrum in the field (in Hungarian, with English abstract). Magy Allatorvosok 9, 507-515. 